\title{
ARCHAEOLOGIA:
}

\author{
OR, \\ M I S C E L L A N E O U S T R A C T S
}

RELATING TO

ANTIQUITY. 


\title{
ARCHAEOLOGIA :
}

\author{
- \\ M I S C E L L A N E O U S T R A C T S \\ RELATING TO \\ A N T I Q U I T Y, \\ PUBLISHED BY THE
}

SOCIETY OF ANTIQUARIES OF LONDON.

VOLUME XXXVI.

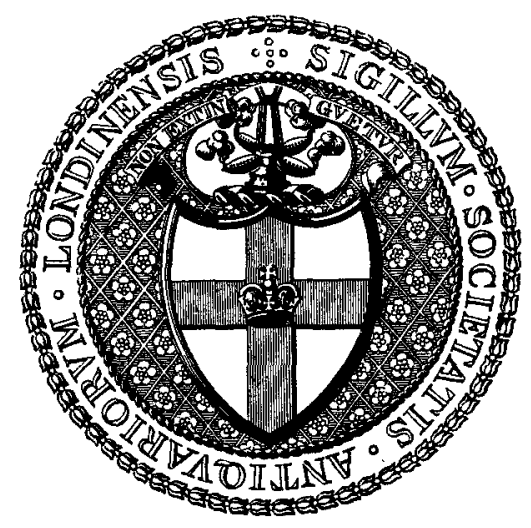

LONDON:

PRINTED BY J. B. NICHOLS AND SONS, 25, PARLIAMENT STREET.

SOLD AT THE SOCIETY'S APARTMENTS IN SOMERSET PLACE;

AND BY JOHN HENRY PARKER, 377, STRAND.

M.DCCC.LV . 
XXII.-Extracts from the Churchwardens' Accounts of the Parish of Wing, in the county of Buckingham. In a Letter addressed by Frederic Odvry, Esq., Treasurer $S A$., to John Payne Collier, Esq., Vice-President ～- - - - 219-2411

XXIII.-Journal of the Mission of Queen Isabella to the Court of France, and of her long residence in that country. Communicated by JosEPH HunTER, one of the Vice-Presidents -

XXIV.-Sépultures Chrétiennes de la période Anglo-Normande, trouvées à Bouteilles, près Dieppe, en 1855. Par M. L'ABbe CocheT

$258-266$

XXV.-Remarks upon two Original Deeds relating to Sir Thomas Swinford, the son of Catherine Swinford, who was afterwards the wife of John of Gaunt. By JosePh Hunter, Esq., VicePresident - $\quad$ - $\quad$ - $\quad$ - $\quad$ - $\quad$ $267-269$

XXVI.-On Mortuary Urns found at Stade-on-the-Elbe, and other parts of North Germany, now in the Museum of the Historical Society of Hanover. By John Mitchell Kemble, Esq., in a Letter

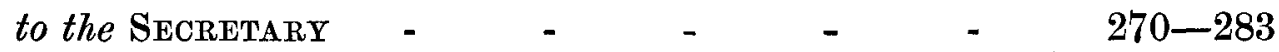

XXVII.-Extracts from the Private Account Book of Sir William More, of Loseley, in Surrey, in the time of Queen Mary and of Queen Elizabeth. Communicated in a Letter from JoHn Evans, Esq., F.S.A., to J. Y. Akerman, Esq., Secretary - 284-310 XXVIII.-Medieval Architecture in Aquitaine; in continuation and conclusion of previous Papers. A Letter addressed to the EARL Stanhope, President, by John Henry Parker, Esq., F.S.A.

$311-325$

XXIX.- Notes on Bronze Weapons found on Arreton Down, Isle of Wight. By Augustus W. Franks, Esq., F.S.A. In a Letter to Sir Henky ELuIs, K.H., F.R.S., Director ～- $326-331$

XXX.- History of the Boat which gave Peter the Great the first Thought of building the Russian Fleet. Communicated by Sir Henry Elims, $K . H$. ., Director, in a Letter to the President

$332-338$

XXXI.-On Sir Nicholas Bacon, Lord Keeper; with Extracts from some of his unprinted Papers and Speeches. By JоHN PaYNE Collier, Esq., V.P.S.A.

$339-384$ 
viii CONTENTS.

PAGE

XXXII.-On some remarkable Sepulchral Objects from Italy, Styria, and Mecklenburgh. By JoHn MitcheuL Kemble

$349-369$

XXXIII.-Observations on a Picture in Glowcester Cathedral, and some other Representations, of the Last Judgment. By G. SCHARF, Esq., Junior, F.S.A.

$370-391$

XXXIV.-On Episcopal and other Rings of Investiture. By Octavius Morgan, Esq., M.P., F.S.A.

$392-399$

XXXV.-On the Abbot of Waltham's House, in the Parish of Saint Maryat.Hill, London. By G. R. ConNen, Esq., F.S.A. In a Letter to Sir Henry Eliss, K.H., F.R.S., Director $400-417$

XXXVI.-Excavations prosecuted by the Caerleon Archaological Association within the Walls of Caerwent in the Summer of 1855. By Octavius Morgan, Esq., M.P., F.S.A. $418-437$ XXXVII.-The Old Tapestry in St. Mary's Hall at Coventry. By George Scharf, Junior, Esq., F.S.A. - - - $\quad 438-453$ XXXVIII.-On Horse-trappings found at Westhall. In a Letter from Heinry Harrod, Esq., F.S.A., to J. Y. Akerman, Esq.,

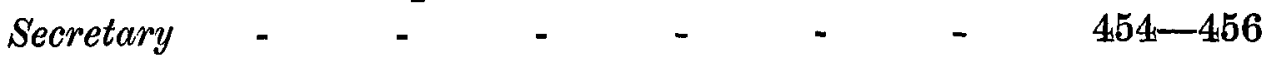
Addenda to Mr. SchaRF's Memoir on Paintings of the Last Judgment

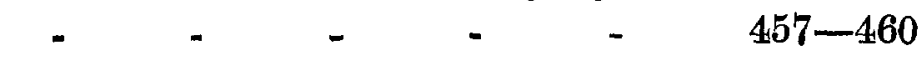




\section{TABLE OF PLATES.}

PLATE

PAGE

I. Window from the Church of Marcadell, at Bazas, with the Arch-

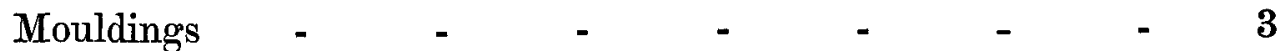

II. Part of the Choir and Plan of the Church at Uzeste, A.D. 1314 - 4

III. Part of the Choir and Transept of S. Caprais, Agen - $\quad$ - 6

IV. Capitals from the Cloister at Moissac, A.D. 1100 - - $\quad$ - 10

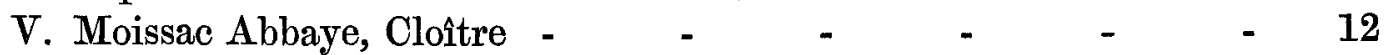

VI. Vase representing an Adventure of Perseus - $\quad$ - $\quad$ - 70

VII. Heads of Missile Weapons found at Salisbury - $\quad-\quad-72$

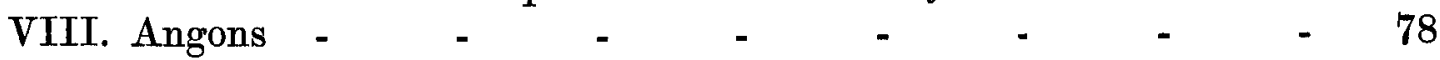

IX. Plan of Upper and Lower Warbank Fields; and of others in

Keston Court Farm, Kent; showingthe Site of Roman Foundations there, discovered in October, 1854 $\quad-\quad-\quad-\quad-127$

X. Remains of Roman Foundations at Keston $\quad-\quad$ - $\quad$ - 127

$\mathrm{XI}$.)

XII. Plates illustrative of the Interments of the Alemanni at Oberflacht

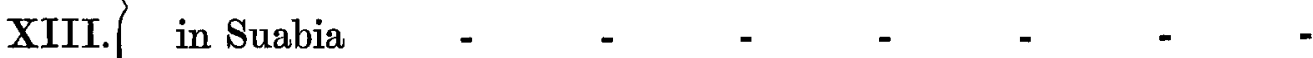

XIV.

XV. Hieroglyphic Inscriptions from different parts of a Mummy unrolled at Florence $\quad-\quad\left[\begin{array}{llllllll} & - & - & - & - & - & \mathbf{1 7 4}\end{array}\right.$

XVI. Objects found in a Tumulus at Stodmarsh, in Kent $\quad$ - $\quad$ - 179

XVII. Silver Rings and Coins found near Worcester - - - $\quad 202$

XVIII. Plan of the Buildings of the Excise Office, shewing the Site of the Roman Pavement discovered there in 1854 - - - 203

XIX. Plan of the Pavement - - - - - - - - 204

XX. Plan of London and its Vicinity to the South-East, shewing the Lines of the Roman Roads and their probable continuation in Roman London 
$\mathbf{x}$

PAGE

XXI. Tombeaux Chretiens, trouvés a Bouteilles près Dieppe $\quad$ - 266

XXII. Mortuary Urns from Stade on the Elbe $\quad-\quad \quad$ - $\quad$ - 282

XXIII. Mortuary Urns from Hoya, Nienburg, Woolpe, and the neighbourhood of the Weser $\quad$ - $\quad$ - $\quad \ldots \quad$ - $\quad$ - 282

XXIV. Mortuary Urns from the Watershed of the Ilmerau and its

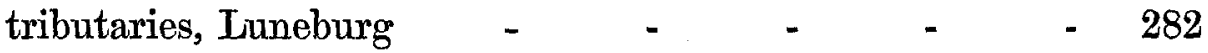

XXV. Bronze Weapons found at Arreton Down, Isle of Wight $\quad$ - 330

XXVI. Sepulchral Objects from Italy and Germany - $\quad-\quad 350$

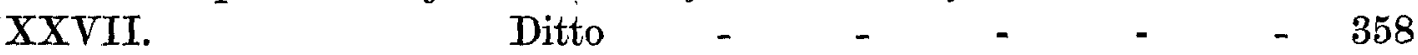

XXVIII. From a large Picture in the South Triforium of Gloucester

Cathedral, representing the Last Judgment $\quad-\quad \quad \quad 370$

XXIX. Pages of a Cottonian MS. marked Nero C. iv. in the British

Museum, relating to the Last Judgment - - - -

378

XXX. Key Sketches to illustrate Mr. Scharf's Paper on Representa-
tions of the Last Judgment

XXXI.)

XXXII. Pitto Ditto

Ditto - $\quad-\quad 386$

XXXIII. Plan of Caerwent, in the county of Monmouth, 1855 - $\quad$ - 418

XXXIV. Tessellated Pavement discovered February 1777 at Caerwent - 428

XXXV. Ground Plan of a Roman Building at Caerwent with Tessel-

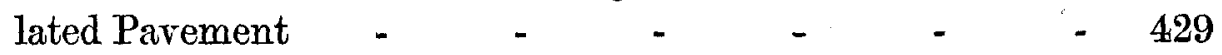

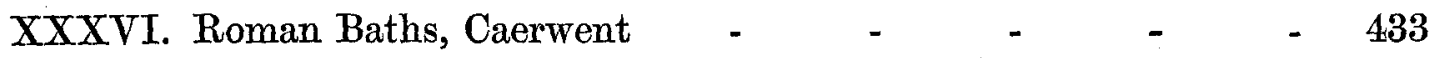

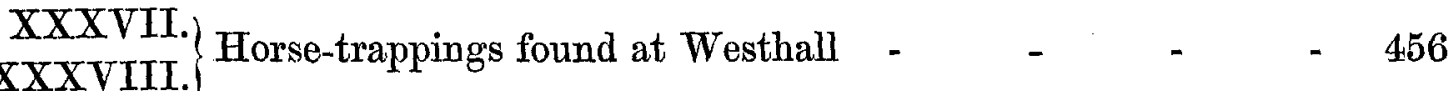

